\title{
The Etiological Factors of Duodenal and Gastric Ulcers
}

\author{
Ahmet Uyanıkoğlu ${ }^{1}$, Ahmet Danalığ $l^{1}{ }^{1}$, Filiz Akyüz ${ }^{1}$, Binnur Pınarbaşı1, \\ Mine Güllüoğlu², Yersu Kapran², Kadir Demir ${ }^{1}$, Sadakat Özdil ${ }^{1}$, Fatih

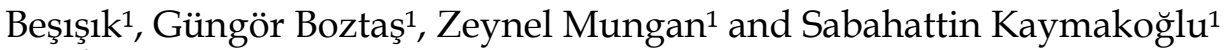 \\ ${ }^{1}$ Istanbul University, Faculty of Medicine, Department of Gastroenterohepatology, \\ ${ }^{2}$ Istanbul University, Faculty of Medicine, Department of Pathology \\ Turkey
}

\section{Introduction}

\subsection{Background}

Peptic ulcer disease (PUD) had a tremendous effect on morbidity and mortality until the last decades of the $20^{\text {th }}$ century. Development of new effective and potent acid suppressants and the discovery of Helicobacter pylori (H. pylori) are two important steps that caused a reduction in the prevalence of peptic ulcer. With the discovery of $\mathrm{H}$. pylori, causes, pathogenesis and treatment of PUD have been defined again in the last 25 years. However, this condition continues to be an important clinical issue because of common use of nonsteroidal anti-inflammatory drugs (NSAID) and acetylsalicylic acid at low doses. The rare but increasingly problematic issue is H pylori-negative and NSAID-negative ulcers (1). Despite progress in diagnosis and treatment, peptic ulcer disease (PUD) remains a common reason for hospitalization and operation (2).

Peptic ulcer disease (PUD) affects 10\% of the world population. Helicobacter pylori infection and the use of a nonsteroidal anti-inflammatory drug (NSAID) are the principal factors associated with PUD (3). The declining global prevalence of peptic ulcer disease (PUD) might be because of the decreasing prevalence of Helicobacter pylori (Hp) infection (4). The decreasing prevalence of $\mathrm{H}$. pylori could lead to a relative increase in the number of patients with this NSAID associated and idiopathic peptic ulcer disease (IPUD (5). Another view is that incidence of peptic ulcers decreased and an increasing proportion was related to NSAID and the Mortality was high (6). It is also known that the incidence of idiopathic peptic ulcer disease has increased $(7,8)$.

$\mathrm{H}$ pylori infection causes both gastric and duodenal ulcers (35-27). Current data shows that $\mathrm{H}$ pylori infection plays a major role in peptic ulcer disease and non-ulcer dyspepsia $(9,10)$. Apart from these diseases, $\mathrm{H}$ pylori are thought to play a role in the etiology of atrophic gastritis, gastric adenocarcinoma and lymphoma. In our country, $\mathrm{H}$. pylori prevalence remains an important health problem (11).

The aim of this study is to determine the etiology of patients with duodenal and gastric ulcers. 


\section{Materials-methods}

Between April 2002 and April 2009, 140 patients who referred to our endoscopy laboratory with dyspeptic complaints for gastroscopy and diagnosed with peptic ulcer (duodenal and/or gastric) were enrolled to this prospective study. Before the procedure, medical history, cigarette smoking and alcohol consumption and nonsteroidal anti-inflammatory drugs (NSAIDs) and acetylsalicylic acid use within the last month were queried. Patients with a history of gastric operation, with malign ulcer or another malign disease and who were not willing to participate the study were excluded.

Two biopsy specimens were collected from antrum and corpus for histology and one for rapid urease testing and stool samples were analyzed for Helicobacter pylori (H pylori) antigen using Laboquick $\mathrm{H}$ pylori antigen test kit. A patient was classified as being H. pylori positive if any of the three test methods were positive. NSAID and/or acetylsalicylic acid use within the last month was associated with ulcer, if any. Inflammatory activity, intestinal metaplasia, atrophy and H. pylori were evaluated in histopathological examination. Serum calcium and gastrin levels were also analyzed.

SPSS 13.0 statistical program was used for statistical assessments. Mean \pm standard deviation (SD) or median were used for quantitative variables. For independent group comparisons, intergroup variations were analyzed with non parametrical Mann -Whitney $U$ test. Inter group variations were evaluated using Wilcoxon test (for dependent group comparison). Correlation analyses were performed using Pearson and Spearman correlation tests. Results with "p value" less than 0.05 were accepted as statistically significant.

\section{Results}

82 of the patients (58\%) were male and $58 \%$ were female (42\%). Mean age was $47.70 \pm 15.03$ (range 16-92). 62 of the patients (44\%) were smoking and $18(13 \%)$ were drinking alcohol. 132 of the patients $(94 \%)$ were from urban whereas $8(6 \%)$ were from rural areas. 14 patients $(10 \%)$ had a family history of PUD, whereas $4(0.3 \%)$ had a family history of stomach cancer. Ulcer was located in duodenum in 96 patients $(69 \%)$, in stomach in 40 patients $(28 \%)$, and both in duodenum and stomach in 4 patients (3\%).

Rate of patients tested positive for $\mathrm{H}$ pylori antigen in stool, positive in urease testing and tested positive for $\mathrm{H}$. pylory presence in antral and corpus samples were $48 \%, 52 \%, 67 \%$ and $60 \%$ respectively (see Table 1 ). 107 patients $(76 \%)$ were positive for $\mathrm{H}$. pylori in one of the test methods.

\begin{tabular}{|l|l|}
\hline Method & Incidence \\
\hline Stool sample for H pylori positive & $48 \%$ \\
\hline Rapid urease testing positive & $52 \%$ \\
\hline H pylori positive antral histology & $67 \%$ \\
\hline H pylori positive corpus histology & $60 \%$ \\
\hline H pylori positive with any method & $76 \%$ \\
\hline
\end{tabular}

Table 1. Incidence of $\mathrm{H}$. pylori in peptic ulcer using various methods.

Among 64 patients (46\%) with a story of nonsteroidal antienflammatory drug (NSAID) use within the last 1 month, 48 (75\%) were Hp positive and 16 were (25\%) negative (see Table 2). 
Mean age of patients on NSAID therapy higher $51.26 \pm 15.60$ (range 21-92) compared to the non-users $45.32 \pm 14.25$ (range 16-80) $(\mathrm{p}<0.05)$.

\begin{tabular}{|l|l|ll|}
\hline H pylori positive PUD & 107 & $76 \%$ & \\
\hline NSAID use & 64 & & $(46 \%)$ \\
NSAID+H pylori positive & & 48 & $(75 \%)$ \\
$\begin{array}{l}\text { NSAİ̈+ H pylori } \\
\text { negatifliği }\end{array}$ & & $12 \%$ & $(25 \%)$ \\
\hline Idiopathic PUD & 17 & & $12 \%$ \\
\hline
\end{tabular}

Table 2. Peptic ulcer (PUD) etiology

Incidence of inflammatory activity, atrophy and intestinal metaplasia were $65 \%, 17.5 \%$ and $11 \%$ in antral biopsies and $66 \%, 6.5 \%$ and $1.5 \%$ in corpus samples, respectively (see Table 2).

\begin{tabular}{|l|l|l|}
\hline & Antrum & Corpus \\
\hline Inlammatory activity & $65 \%$ & $66 \%$ \\
\hline Atrophy & $17.5 \%$ & $6.5 \%$ \\
\hline Intestinal metaplasia & $11 \%$ & $1.5 \%$ \\
\hline H. pylori incidence & $67 \%$ & $60 \%$ \\
\hline
\end{tabular}

Table 3. Histology findings of the biopsy samples

Histopathologically inflammatory activity was correlated with $\mathrm{H}$. pylori $(\mathrm{p}<0.05)$. Mean levels of calcium and gastrin were $9.29 \pm 0.40$ (7.90-10.20) and $73.96 \pm 89.88$ (12.86-562.50) respectively. In patients with elevated gastrin levels, no hypersecretory condition was detected. Elevated levels of gastrin were correlated with inflammatory activity and presence of H. pylori $(\mathrm{p}<0.05)$.

19 of patients $(13.6 \%)$ were negative for H pylori, NSAID use and hypersecretory illness and classified as idiopathic. Mean age of these pateints were $51.52 \pm 13.88$ (range 16-78). Ulcer was located in the duodenum of 13 patients $(68 \%)$ and in stomach of 6 patients (32\%). 11 of the patients $(58 \%)$ were male and $8 \%$ were female $(42 \%) .9$ of the patients $(47 \%)$ were smoking and $3(16 \%)$ were drinking alcohol. 1 patient had a family history of PUD and 1 had a family history of stomach cancer. Mean age of these patients was higher compared to patients with a known etiology $(\mathrm{p}<0.05)$, however there were no statistical differences in terms of ulcer location, gender, smoking, alcohol consumption, and family history ( $\mathrm{p}>0.5)$. Mean gastrin level of $60.07 \pm 64.13$ (12.86-183.61) was lower compared to the patients with a known etiology $(p<0.05)$ whereas calcium levels of $9.33 \pm 0.6(7.9-10.2)$ were similar $(p>0.5)$.

\section{Discussion}

54 (19\%) of 277 consecutive patients had evidence of peptic ulcer disease (34 gastric ulcer, 14 duodenal ulcer and 6 both gastric and duodenal ulcer) in a similar study where demographic and endoscopic characteristics of patients with Helicobacter pylori positive and negative chronic peptic ulcer disease were evaluated (12). The most common finding in this study was gastric ulcer whereas in our study, among 140 patients with PUD 96 (69\%) had duodenal ulcer, 40 had (28\%) gastric ulcer and 4 had (3\%) both duodenal and gastric 
ulcer in our study. These variations may be associated with the regional characteristics, lower number of patients evaluated in the other study and etiological differences.

Helicobacter pylori infection and the use of a nonsteroidal anti-inflammatory drug (NSAID) are the principal factors associated with PUD (3). Similarly, etiologic factor in $88 \%$ of patients in our study was H pylori and/or NSAID use.

While incidence of PUD associated with $\mathrm{H}$ pylori infection is decreasing especially in western countries $(5,7,8)$, in our country most common cause is $\mathrm{H}$ pylori $(76 \%)$. It may be associated with the fact that $\mathrm{H}$. pylori prevalence remains an important health problem in our country and prevalence in the community is very high. In a study performed in our country with 9239 patients who underwent gastrointestinal endoscopy, H. pylori incidence was $41.44 \%$ using the CLO test (11).

In a study where demographic and endoscopic characteristics of peptic ulcer were evaluated, urease, culture, histology and serum anti-H pylori IgG antibody were evaluated in patients and demographic data as well as NSAID use within the last 3 months were assessed. $56 \%$ of patients were $\mathrm{H}$ pylori positive and $22 \%$ were using NSAIDs $(70 \%$ were $\mathrm{H}$ pylori positive) (12). In our study $H$. pylori was evaluated using urease testing, $H$ pylori antigen in stool and histology and rate of patients who are $\mathrm{H}$ pylori positive and using NSAIDs within the last month were higher (76\% and $46 \%$ respectively). Similarly, some patients using NSAID (75\%) were also H pylori positive.

H. pylori induces chronic inflammation of the gastric mucosa, but only a proportion of infected individuals develop peptic ulcer disease or gastric carcinoma Reasons underlying these observations include differences in bacterial pathogenicity as well as in host susceptibility (13). Meta-analyses showed that Helicobacter pylori eradication therapy was effective for healing and prevention of recurrence of peptic ulcers in $\mathrm{H}$. pylori-positive patients and that treatment of $\mathrm{H}$. pylori infection was more effective than antisecretory noneradicating therapy (with or without long-term maintenance therapy) in preventing recurrent bleeding (14). $\mathrm{H}$ pylori eradication has been associated with decreased risk of gastric cancer in patients with peptic ulcer diseases (15). In our study, $\mathrm{H}$ pylori were also correlated with inflammatory activity. When it is considered that the $\mathrm{H}$ pylori associated PUD is a common disease in our country, we should give more importance to eradication therapy both for effective treatment of PUD and for cancer prophylaxis.

NSAIDs have known detrimental side effects on the gastrointestinal system. The risk is increased with older age and history of PUD. Helicobacter pylori infection and cardioprotective acetylsalicylic acid have additive risks in the presence of NSAID use (16). The development of PUD was observed earlier in the combined $\mathrm{H}$ pylori and NSAID group than in patients with only NSAID use and this suggests a synergic effect between the two risks factors in the development of PUD (3). In our study, 75\% of patients with history of NSAID therapy were $\mathrm{H}$ pylori positive. This finding suggest that $\mathrm{H}$ pylori and NSAID usage, when together, increases the risk of PUD.

Apart from $\mathrm{H}$ pylori and NSAID, risk factors such as smoking, alcohol intake, age, and male gender were reported as contributing to the gastric and duodenal ulcer development (1720). In our study, patients who are supporting these findings were at middle or older age and $58 \%$ of them were male. Almost half of the patients $(44 \%)$ were smokers and $13 \%$ were drinking alcohol.

Rate of patients classified as idiopathic (H pylori negative, NSAID negative) were reported between 4 and $20 \%(5,8,17)$. Among 140 patients 19 were $(13 \%) \mathrm{H}$ pylori and NSAID 
negative. Idiopathic ulcer was reported among younger patients in a study (12) where as 19 patients classified as idiopathic in our study were older compared to patients with a known etiology.

Apart from $\mathrm{H}$ pylori, poor socio-economic status has been reported as an important risk factor for PUD infection while genetic factors do not influence the risk of PUD (21). Although the socio-economic status of the patients enrolled in our study has not been investigated in detail, 132 of the patients (94\%) were from the urban regions while $8(6 \%)$ were from the rural area and $14(10 \%)$ had a history of ulcer.

As a consequence, most common cause of duodenal and gastric ulcer is $\mathrm{H}$. pylori and is responsible for three-fourths of the cases. About half of the patients had a history of NSAID use and NSAID and H. pylori are both responsible for the ulcer in three-forths of these patients. In one tenth of the patients, NSAID use was the cause of ulcer alone and about onetenth of the ulcers were classified as idiopathic.

\section{References}

[1] Malfertheiner P, Chan FK, McColl KE. Peptic ulcer disease. Lancet. 2009 Oct 24;374(9699):1449-61. Epub 2009 Aug 13.

[2] Wang YR, Richter JE, Dempsey DT. Trends and outcomes of hospitalizations for peptic ulcer disease in the United States, 1993 to 2006. Ann Surg. 2010 Jan;251(1):51-8.

[3] Zapata-Colindres JC, Zepeda-Gómez S, Montaño-Loza A, Vázquez-Ballesteros E, de Jesús Villalobos J, Valdovinos-Andraca F. The association of Helicobacter pylori infection and nonsteroidal anti-inflammatory drugs in peptic ulcer disease. Can J Gastroenterol. 2006 Apr;20(4):277-80.

[4] Wong SN, Sollano JD, Chan MM, Carpio RE, Tady CS, Ismael AE, Judan-Ruiz EA, Ang VN, Go JT, Lim VY, Perez JY, Alvarez SZ. Changing trends in peptic ulcer prevalence in a tertiary care setting in the Philippines: a seven-year study. J Gastroenterol Hepatol. 2005 Apr;20(4):628-32.

[5] Arents NL, Thijs JC, van Zwet AA, Kleibeuker JH. Does the declining prevalence of Helicobacter pylori unmask patients with idiopathic peptic ulcer disease? Trends over an 8 year period. Eur J Gastroenterol Hepatol. 2004 Aug;16(8):779-83.

[6] Lassen A, Hallas J, Schaffalitzky de Muckadell OB. Complicated and uncomplicated peptic ulcers in a Danish county 1993-2002: a population-based cohort study. Am J Gastroenterol. 2006 May;101(5):945-53.

[7] Jang HJ, Choi MH, Shin WG, Kim KH, Chung YW, Kim KO, Park CH, Baek IH, Baik KH, Kae SH, Kim HY. Has Peptic Ulcer Disease Changed During the Past Ten Years in Korea? A Prospective Multi-center Study. Dig Dis Sci. 2007 Oct

[8] Arroyo MT, Forne M, de Argila CM, Feu F, Arenas J, de la Vega J, Garrigues V, Mora F, Castro M, Bujanda L, Cosme A, Castiella A, Gisbert JP, Hervas A, Lanas A. The prevalence of peptic ulcer not related to Helicobacter pylori or non-steroidal antiinflammatory drug use is negligible in southern Europe. Helicobacter. 2004 Jun;9(3):249-54.

[9] Kachintorn U, Luengrojanakul P, Atisook K, Theerabutra C, Tanwandee T, Boonyapisit S, Chinapak O. Helicobacter pylori and peptic ulcer diseases: prevalence and association with antral gastritis in 210 patients. J Med Assoc Thai. 1992 Jul;75(7):386-92. 
[10] Itoh T, Seno H, Kita T, Chiba T, Wakatsuki Y. The response to Helicobacter pylori differs between patients with gastric ulcer and duodenal ulcer. Scand J Gastroenterol. 2005 Jun;40(6):641-7.

[11] Sari YS, Sander E, Erkan E, Tunali V.J Gastroenterol Hepatol. Endoscopic diagnoses and CLO test results in 9239 cases, prevalence of Helicobacter pylori in Istanbul, Turkey. 2007 Nov;22(11):1706-11.

[12] Xia HH, Phung N, Kalantar JS, Talley NJ. D.Med J Aust. 2000 Nov 20;173(10):508-9.

[13] Costa AC, Figueiredo C, Touati E. Pathogenesis of Helicobacter pylori infection. Helicobacter. 2009 Sep;14 Suppl 1:15-20.

[14] Satoh K, Sugano K. Helicobacter pylori eradication therapy for peptic ulcer disease. Nippon Rinsho. 2009 Dec;67(12):2322-6.

[15] Wu CY, Kuo KN, Wu MS, Chen YJ, Wang CB, Lin JT. Early Helicobacter pylori eradication decreases risk of gastric cancer in patients with peptic ulcer disease. Gastroenterology. 2009 Nov;137(5):1641-8.e1-2. Epub 2009 Aug 5.

[16] Gupta M, Eisen GM. NSAIDs and the gastrointestinal tract. Curr Gastroenterol Rep. 2009 Oct;11(5):345-53.

[17] Konturek SJ, Bielå̊,ski W, PÅ,onka M, Pawlik T, Pepera J, Konturek PC, Czarnecki J, Penar A, Jedrychowski W. Helicobacter pylori, non-steroidal anti-inflammatory drugs and smoking in risk pattern of gastroduodenal ulcers. Scand J Gastroenterol. 2003 Sep;38(9):923-30.

[18] Anda RF, Williamson DF, Escobedo LG, Remington PL. Smoking and the risk of peptic ulcer disease among women in the United States. Arch Intern Med. 1990 Jul;150(7):1437-41.

[19] Wu HC, Tuo BG, Wu WM, Gao Y, Xu QQ, Zhao K. Prevalence of peptic ulcer in dyspeptic patients and the influence of age, sex, and Helicobacter pylori infection. Dig Dis Sci. 2008 Oct;53(10):2650-6. Epub 2008 Feb 13.

[20] Salih BA, Abasiyanik MF, Bayyurt N, Sander E. H pylori infection and other risk factors associated with peptic ulcers in Turkish patients: a retrospective study. World J Gastroenterol. 2007 Jun 21;13(23):3245-8.

[21] Rosenstock SJ, JÃ rgensen T, Bonnevie O, Andersen LP. Does Helicobacter pylori infection explain all socio-economic differences in peptic ulcer incidence? Genetic and psychosocial markers for incident peptic ulcer disease in a large cohort of Danish adults. Scand J Gastroenterol. 2004 Sep;39(9):823-9. 


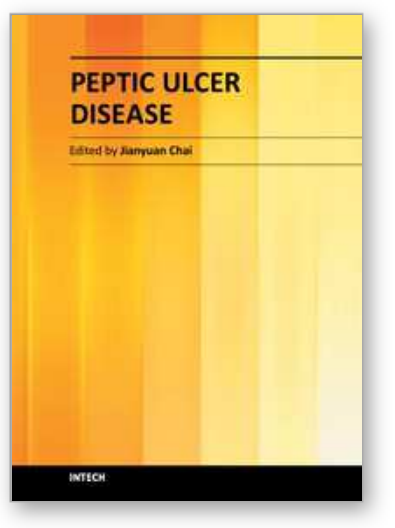

\author{
Peptic Ulcer Disease \\ Edited by Dr. Jianyuan Chai
}

ISBN 978-953-307-976-9

Hard cover, 482 pages

Publisher InTech

Published online 04, November, 2011

Published in print edition November, 2011

Peptic ulcer disease is one of the most common chronic infections in human population. Despite centuries of study, it still troubles a lot of people, especially in the third world countries, and it can lead to other more serious complications such as cancers or even to death sometimes. This book is a snapshot of the current view of peptic ulcer disease. It includes 5 sections and 25 chapters contributed by researchers from 15 countries spread out in Africa, Asia, Europe, North America and South America. It covers the causes of the disease, epidemiology, pathophysiology, molecular-cellular mechanisms, clinical care, and alternative medicine. Each chapter provides a unique view. The book is not only for professionals, but also suitable for regular readers at all levels.

\title{
How to reference
}

In order to correctly reference this scholarly work, feel free to copy and paste the following:

Ahmet Uyanıkoğlu, Ahmet Danalıoğlu, Filiz Akyüz, Binnur Pınarbaşı, Mine Güllüoğlu, Yersu Kapran, Kadir Demir, Sadakat Ozdil, Fatih Beşışık, Güngör Boztaş, Zeynel Mungan and Sabahattin Kaymakoğlu (2011). The Etiological Factors of Duodenal and Gastric Ulcers, Peptic Ulcer Disease, Dr. Jianyuan Chai (Ed.), ISBN: 978953-307-976-9, InTech, Available from: http://www.intechopen.com/books/peptic-ulcer-disease/the-etiologicalfactors-of-duodenal-and-gastric-ulcers

\section{INTECH}

open science | open minds

\author{
InTech Europe \\ University Campus STeP Ri \\ Slavka Krautzeka 83/A \\ 51000 Rijeka, Croatia \\ Phone: +385 (51) 770447 \\ Fax: +385 (51) 686166 \\ www.intechopen.com
}

\author{
InTech China \\ Unit 405, Office Block, Hotel Equatorial Shanghai \\ No.65, Yan An Road (West), Shanghai, 200040, China \\ 中国上海市延安西路65号上海国际贵都大饭店办公楼405单元 \\ Phone: +86-21-62489820 \\ Fax: +86-21-62489821
}


(C) 2011 The Author(s). Licensee IntechOpen. This is an open access article distributed under the terms of the Creative Commons Attribution 3.0 License, which permits unrestricted use, distribution, and reproduction in any medium, provided the original work is properly cited. 